\title{
Problem Solving And Creativity And Design: What Influence Do They Have On Girls' Interest In STEM Subject Areas?
}

Robyn Cooper, Ph.D., Drake University, USA

Carol Heaverlo, Ph.D., Iowa State University, USA

\begin{abstract}
For girls there is a distinct loss in interest, lack of confidence, and decline in positive attitudes toward STEM subject areas that begins early on in their academic experience and increases with age. According to the National Academy of Engineering, students need to begin associating the possibilities in STEM fields with the need for creativity and real world problem solving skills. Recent research has focused on the necessity of emphasizing the use of creativity and design in attracting girls to STEM academic and career fields. Many extra and after school activities (e.g., State Science Fair, math club, environmental club), provide girls with experiential learning that incorporates problem solving and/or creativity and design skills as well as providing investigative opportunities into academic areas that may not be part of the regular school day. Through hierarchical regression analyses, this study examined the extent to which middle and high school girls' $(n=915)$ age, and interest and confidence in a) problem solving and b) creativity and design predicted their interest in four STEM subject areas. A follow up analysis identified the extracurricular activities in which girls with higher interests in problem solving and creativity and design were involved. Results revealed that interest in problem solving was a positive predictor for interest in all four STEM subject areas; whereas, interest in creativity and design was a positive predictor for interest in computers and engineering, but a negative predictor for interest in science.
\end{abstract}

Keywords: STEM Subjects; Problem-solving; Problem-based Learning; Creativity; Design; Extracurricular

\section{INTRODUCTION}

$\mathscr{Q}$ nited States Department of Labor workforce projections for 2018 indicate that nine of the 10 fastest growing occupations will require substantial science or mathematics education (National Science Board, 2010). Science, Technology, Engineering, and Mathematics (STEM) fields play a critical role in shaping culture and economic development through innovation, creativity, and problem solving. According to Bottoms and Uhn (2007), employers are looking for candidates who possess strong STEM backgrounds. If the United States is to remain globally competitive it must improve STEM literacy in the K-12 classroom and commit to a critical initiative of ensuring that all students develop the knowledge and skills to fully participate in the $21^{\text {st }}$ century workforce (NAS, 2010). For students in K-12 to acquire the skills and knowledge necessary to pursue college degrees in STEM programs, it is critical to cultivate their interests in STEM subject areas early in their education (Denissen, Zarrett, \& Eccles, 2007; Jeffers, Safferrman, \& Safferman, 2004; Shuen, et al., 2011). Furthermore, a primary predictor of whether students pursue a STEM career upon completion of high school is their interest in a STEM career at the beginning of high school (Sadler, Sonnert, Hazari, \& Tai, 2012). Maintaining interest in STEM subject areas is even more critical for girls. Throughout high school, Sadler et al. (2012) noted that the "percent of males interested in a STEM career remained stable (from 39.5 to 39.7), whereas for females it declined from 15.7 to 12.7 " (p. 411). 
According to the report Why so Few (AAUW, 2010), girls' interest and achievement in STEM subject areas is affected by historical and invalid stereotypes that impact a girl's perception of her ability to perform well in those academic areas. Two stereotypes prevalent in the literature are boys are better at math and science than girls, and science and engineering careers are better suited for males (AAUW, 2010; Andre et al., 1999; Herbert \& Stipek, 2005; Jacobs et al., 2002; Simpkins, Davis-Kean, \& Eccles, 2006). Research has shown that the gender gap in middle and high school math and science test scores and achievement are no longer statistically significant (AAUW, 2004; Planty et al., 2009). However, for girls there is a distinct loss in interest, lack of confidence, and decline in positive attitudes toward STEM subject areas that begins early on in their academic experience and increases with age (AAUW, 1998; Brotman \& Moore, 2008; Catsambis, 1995; Fennema, 2000; Hebert \& Stipek, 2005). Miller, Blessing, and Schwartz (2006) found that girls' perceptions toward science are that it is uninteresting and difficult.

\section{RELATED LITERATURE}

Research has shown that for STEM subject areas girls learn best in environments that promote collaborative learning, hands-on experiences, creativity, and practical applications (AAUW, 2000; Campbell et al., 2002; Kafai, 1998; Koch, 2002; Wenglinksy, 2000). Given that girls' interest in STEM careers is impacted by their interest in STEM subject areas (Sadler et al., 2012), it is important to distinguish specific skills and activities in K12 education that help to cultivate girls' interest in STEM subject areas. Problem solving and creativity and design have been identified as essential skills in students' STEM development (Baine, 2009; NAE, 2008). Modi, Schoenberg, and Salmond (2012) found that for girls who are interested in STEM, 87\% also indicated an interest in problem solving; compared with those girls not interested in STEM, only 70\% indicated an interest in problem solving.

Three pedagogical methods that use a problem solving approach are Problem-based Learning, Projectbased science, and anchored instruction. Problem Based Learning (PBL), an instructional method originally developed in medical schools, has become increasingly popular in K-12 and higher education (Hunt, LockewoodCooke, \& Kelley, 2010; Hmelo-Silver, 2004). University STEM degree programs are also finding success with PBL (e.g., Davis, Lockwood-Cooke, \& Hunt, 2011; Hunt et al., 2010). This method of instruction encourages students to work collaboratively in small groups to solve challenging, realistic ill-structured problems. PBL is an iterative process that encourages students to 1) identify the problem; 2) research the problem, determine the root cause(s), and clarify the problem; 3) collaboratively generate alternative possible solutions; 4) assess the strength and weaknesses of the potential solutions; 5) determine the best solution; 6) test the solution; and 7) establish criteria for determining the effectiveness of the solution (Hmelo-Silver, 2004).

Project-based Science (PBS) is a pedagogical method grounded in problem solving experiences specific to scientific inquiry (Krajcik et al., 1998). In this approach, the problem is addressed through the scientific inquiry process (i.e., prediction, observation, explanation). Components of PBS include: 1) a rich, complex driving question that is relevant to students' lives, 2) production of artifacts, 3) student-centered learning, 4) collaboration, 5) accountability, 6) authentic use of technology, 7) interdisciplinary and cross-disciplinary inquiry, 8) extended time frame, and 9) valid and reliable performance-based assessment (Colley, 2008, p. 25).

Anchored instruction is grounded in a story illustrated through visually-rich environments using technology that puts students in the context of a problem. Principles of anchored instruction include: 1) a realistic event, in which the problem is anchored or focused, 2) students take ownership of the problem and determine how to break down the problem into smaller components (sub-problems), and 3) students take on different perspectives or roles to identify solutions (Bransford, Vye, Kinzer, \& Risko, 1990). Knowledge gained through anchored instruction is highly transferable to other real life situations.

Common across all problem solving approaches to learning is that the problem and potential solutions are the motivators for student learning. Collaboration is another key aspect to all three problem-solving approaches. Well-devised problems in any of these instructional methods often require students to draw from and apply their knowledge from different content areas and communication skills to generate viable solutions. In addition to drawing knowledge across multidisciplinary subjects, participating in a curriculum with problem-solving experiences fosters higher levels of epistemic and intellectual development in students (King \& Kitchener, 1994; Schraw, Dunkle, \& Bendixen, 1995). 
Regardless of which problem solving instructional method is used, developing problem solving skills foster critical thinking skills and along with creativity serve as cognitive constructs that have been identified as vital to student success in the $21^{\text {st }}$ century. Silva (2008) notes "it is an emphasis on what students can do with knowledge, rather than what units of knowledge they have, that best describes the essence of $21^{\text {st }}$ century skills" (p. 2). Seventysix percent of business leaders from U.S. companies surveyed about skills necessary for the emerging workforce to navigate the changing global economy indicated that the significance for problem solving skills and creativity will continue to increase considerably as the complexity of problems in need of solutions grows (Partnership for $21^{\text {st }}$ Century Skills, 2008a). Furthermore, 70\% of business leaders reported recently hired high schools students were lacking critical thinking and problem solving skills (Partnership for $21^{\text {st }}$ Century Skills, 2008b).

In addition to problem solving skills, creativity and innovation have also been identified within the $21^{\text {st }}$ Century Skills Framework as the aptitude for creativity is essential for generating innovative solutions. Recent research has focused on the necessity of emphasizing the use of creativity and design in attracting girls to the STEM academic and career fields (NAE, 2006; NAE, 2008; AA, 2011). While science is a process of investigation and inquiry, engineering is a process of design that requires a blend of knowledge and creativity (Katehi, Pearson, \& Feder, 2009). "Although engineering is ultimately a creative endeavor, a recent poll shows that only $3 \%$ of U.S. adults perceive engineering as creative" (Harris Interactive, 2004, as cited in Sullivan, 2006, p. 2). Results from the messaging research published in Changing the Conversation: Messages for Improving Public Understanding of Engineering (NAE, 2008), indicated that while many students understood that engineers design and build things, they lack awareness about what engineers actually do. Creativity is such an integral component in engineering and the other STEM fields that some are advocating for a re-focus on STEM to include the arts, recognizing that creativity and innovation skills are necessary in STEM programs and fields (White, 2010). According to Diaz and Cox (2012), while it may not be explicit, at the core of hands-on engineering outreach activities at the K-12 level is the concept of the design process. Additionally, outreach programs that use an art-based thematic approach to bridge the gap in familiarizing middle and high school students with engineering concepts are becoming more prevalent (e.g., Asiabanpour, DesChamps-Benke, Wilson, Loerwald, \& Gourgey, 2010)

Formal science education has traditionally been identified as the pathway for developing scientific literacy among U.S. youth (Bruyere, Billingsly, \& O’Day, 2009). However, Bruyere et al. noted that science achievement can also be enhanced through Informal Science Education (ISE) activities such as extracurricular programs. Recommendations from the report Under the Microscope: A Decade of Gender Equity Projects (AAUW, 2004) also emphasized the importance of extracurricular (informal learning environments) STEM activities. Extracurricular activities play a crucial role in developing interest in STEM areas because the outside of normal class time activities are generally self-selected which means that students who choose to participate often have a fundamental interest or curiosity about the subject area or activity being explored (AAUW, 2004).

Many extra and after school activities (e.g., state science fair, math clubs, 4-H, Mindstorm), provide girls with experiential learning that incorporates problem solving and creativity and design skills as well as providing investigative opportunities into academic areas that are not part of the regular school day. These extracurricular activities play an integral role in shaping interest in STEM subject areas and careers (Bruyere et al., 2009; Darke, Clewell, \& Sevo, 2002). In their research on outreach programs, Anderson and Gilbride (2003) determined that participating in an outreach program with a STEM focus significantly increased girls' interest in pursuing engineering as a career.

The purpose of this study was to determine the extent to which girls' interest and confidence in two key STEM development areas, problem solving and creativity and design, predict their interest in STEM subject areas. Additionally, we explored in which extracurricular activities girls were involved that had higher levels of participant interest in problem solving and creativity and design.

\section{METHODS}

Three research questions guided this study: 
1. Is there a statistically significant difference between girls' interest and confidence in a) problem solving, and b) creativity and design?

2. To what extent does a girl's age, interest in problem solving and creativity and design, and confidence in problem solving and creativity and design, predict their interest in four STEM subject areas: a) science, b) math, c) computer, and d) engineering?

3. Of the extracurricular activities that girls participated in, which activities showed the highest participant mean interest in a) problem solving and b) creativity and design?

\section{Data Collection Procedures and Sample}

Data were collected using a 47-item survey instrument developed by the authors to explore the STEM experiences of middle school and high school girls. Questions on the survey instrument were developed based on theory and prior research regarding the experiences of girls in STEM subjects and activities. The instrument includes four sections: experiences in math and science classes related to teaching factors, extracurricular and after-school involvement, interest and confidence in STEM subject and skill areas, and demographics. Surveys were distributed at three career conferences for girls conducted by The Program for Women in Science and Engineering (PWSE) at Iowa State University (ISU). The PWSE K-12 Outreach Program provides STEM outreach programming for over 9,000 K-12 students per year. One of PWSE's signature outreach programs is the Taking the Road Less Traveled Career Conference for Girls (TRLT). Three conferences are conducted per semester on the ISU campus for $6^{\text {th }}-12^{\text {th }}$ grade girls, parents, teachers, and counselors.

Prior to the start of conference activities, attendees were asked to voluntarily complete the Girls STEM experiences survey. By completing the survey prior to the start of conference activities, we were able to get a more accurate measure of participants' interest in STEM subjects and skills without the influence of conference activities focused on STEM career awareness. A total of 885 middle school girls and 398 high school girls attended one of the three TRLT conferences with 75\% of middle school girls $(n=629)$ and $72 \%$ of high school girls $(n=286)$ completing and returning surveys for a 71\% overall response rate $(n=915)$. Participants' ages ranged from 11 to 18 $(M=13.83, S D=1.54)$. A frequency distribution of participant demographic characteristics is reported in Table 1.

Table 1: Frequency Distribution for Participant Demographics $(n=915)$

\begin{tabular}{lcc}
\hline & $\boldsymbol{n}$ & \% of sample \\
\hline Age & 38 & \\
11 & 136 & 4.2 \\
12 & 237 & 25.9 \\
13 & 249 & 27.2 \\
14 & 105 & 11.5 \\
15 & 94 & 10.3 \\
16 & 45 & 4.9 \\
17 & 11 & 123 \\
18 & & \\
Race/Ethnicity & 753 & 82.3 \\
White & 20 & 2.2 \\
African American & 30 & 3.3 \\
Asian/Pacific Islander & 37 & 4.0 \\
Latina/Hispanic & 9 & 1.0 \\
American Indian/Alaskan Native & 46 & 5.0 \\
Bi-racial/mixed race & 20 & 2.2 \\
Other & & \\
Region of Residence & 316 & 34.5 \\
Rural & 420 & 45.9 \\
Suburban & 118 & 12.9 \\
Urban & 61 & 6.7 \\
Don't Know & & 68.7 \\
School Level & 629 & 31.3 \\
Middle School & 286 & \\
High School & & \\
\hline
\end{tabular}




\section{Variables and Analysis}

Four dependent variables measuring interest in science, math, computer, and engineering subjects were investigated in this study. Each dependent variable was measured through participants' responses to survey questions asking them to rate their level of interest in each STEM subject area using a Likert-type response scale with $1=$ not interested, $2=$ slightly interested, $3=$ interested, and $4=$ very interested.

Independent variables included age (continuous scale), interest in problem solving and creativity and design, and confidence in problem solving and creativity and design. Interest was measured using the same Likerttype response scale as the dependent variables, and confidence was measured using the following Likert-type response scale where $1=$ not confident (I don't think I do well in this activity area), $2=$ slightly confident, $3=$ confident, and $4=$ very confident (I always do well in this activity area).

To answer the first research question, a paired samples $t$-test was used to determine if there was a difference between participants' interest and confidence in a) problem solving and b) creativity and design. Significant differences would help to verify that the concepts of interest and confidence were measuring different effects on the dependent variables as well as identifying whether participants were more interested than confident or vice-versa in problem solving and creativity and design. The second research question was answered by conducting four hierarchical multiple regression analyses, one for each of the dependent variables of interest in science, math, computer, and engineering. In hierarchical regression (sometimes referred to as sequential regression), independent variables are entered in blocks with order of entry specified by the researcher. By entering independent variables in blocks, the effects of each independent variable can be measured at its point of entry (Tabachnick \& Fidell, 2007). Three blocks were used for each regression model with the variable of age entered in the first block, followed by the two variables measuring interest in problem solving and interest in creativity and design, and in the final block the two variables measuring confidence in problem solving and confidence in creativity and design.

\section{RESULTS}

Initial screening of the data was conducted to ensure assumptions of data normality were met; an important consideration when conducting $t$-tests and multiple regression analyses (Green and Salkind, 2011). Furthermore, bivariate correlations for all independent and dependent variables revealed no instances of multicollinearity. Variables that are multicollinear $(r>=.90)$ contain redundant information and are not needed in the same analysis (Tabachnick \& Fidell, 2007). The correlation matrix is shown in Table 2. Because multiple correlations were computed, a Bonferonni approach to control for a Type 1 error was used to determine statistically significant correlations (Green \& Salkind). Thus, $p<.0013(.05 / 36)$ was used to identify statistically significant correlations noted with an asterisk $(*)$ in Table 2 .

Table 2: Correlation Matrix - Independent and Dependent Variables $(n=915)$

\begin{tabular}{|c|c|c|c|c|c|c|c|c|c|}
\hline & & 1 & 2 & 3 & 4 & 5 & 6 & 7 & 8 \\
\hline 1 & Age & -- & & & & & & & \\
\hline 2 & Interest in Problem Solving & -.01 & -- & & & & & & \\
\hline 3 & Confidence in Problem Solving & -.07 & $.66^{*}$ & -- & & & & & \\
\hline 4 & Interest in Creativity \& Design & $-.16^{*}$ & $.22 *$ & $.17 *$ & -- & & & & \\
\hline 5 & Confidence in Creativity \& Design & $-.20 *$ & $.17 *$ & $.29 *$ & $.67 *$ & -- & & & \\
\hline 6 & Science Interest & .04 & $.27 *$ & $.19 *$ & -.02 & .03 & -- & & \\
\hline 7 & Math Interest & -.03 & $.43 *$ & $.31 *$ & .06 & .02 & $.25 *$ & -- & \\
\hline 8 & Computer Interest & -.08 & $.20 *$ & $.12 *$ & $.17 *$ & $.14 *$ & $.13 *$ & $.28 *$ & -- \\
\hline 9 & Engineering Interest & -.05 & $.29 *$ & $.23 *$ & $.15^{*}$ & $.12 *$ & $.28 *$ & $.27 *$ & $.27 *$ \\
\hline
\end{tabular}

Noteworthy are the statistically significant correlations between age and a) interest in creativity and design $(r=-.16, p<.0013)$ and $\mathrm{b})$ confidence in creativity and design $(r=-.20, p<.0013)$ indicating that as girls get older they are less interested and confident in creativity and design. 


\section{Difference between Interest and Confidence}

Results of the two paired samples $t$-tests indicated statistically significant differences between girls' interest and confidence for both problem solving and creativity and design. Specifically, girls in this study reported more confidence $(M=2.80, S D=.891)$ than interest $(M=2.74, S D=.946)$ in problem solving, $t(967)=2.67, p=.008$. In the second paired samples $t$-test, girls in this study reported more interest $(M=3.30, S D=.843)$ than confidence $(M$ $=3.08, \mathrm{~S} D=.901)$ in creativity and design, $t(963)=9.86, p<.001$.

\section{Predictors of Interest in STEM Subject Areas}

Results of the four regression models are summarized in Table 3 with standardized Beta $(\beta)$ coefficients listed for independent variables in each block. For each of the dependent variables in the full model, interest in problem solving was the only positive predictor that was statistically significant across all four regression models. Interest in creativity and design was a positive predictor for interest in computers and in engineering, but a negative predictor for interest in science. The variables of confidence in problem solving and creativity and design, as well as the variable of age, were not statistically significant predictors for interests in any of the STEM subject areas. Following are summative results for each of the four regression models.

Table 3: Standardized Regression Coefficients for Interest in STEM Subject Areas $(n=915)$

\begin{tabular}{|c|c|c|c|c|}
\hline Variables & Science & Math & Computers & Engineering \\
\hline \multicolumn{5}{|l|}{ Block 1} \\
\hline Age & .044 & -.032 & $-.083 *$ & -.052 \\
\hline \multicolumn{5}{|l|}{ Block 2} \\
\hline Age & .036 & -.031 & -.061 & -.035 \\
\hline Interest in Problem Solving & $.285 * * *$ & $.442 * * *$ & $.175 * * *$ & $.275 * * *$ \\
\hline Interest in Creativity \& Design & $-.074 *$ & -.037 & $.126 * * *$ & $.084 * *$ \\
\hline \multicolumn{5}{|l|}{ Block 3 (Full Model) } \\
\hline Age & .044 & -.035 & -.060 & -.032 \\
\hline Interest in Problem Solving & $.275 * * *$ & $.407 * * *$ & $.210 * * *$ & $.237 * * *$ \\
\hline Interest in Creativity \& Design & $-.116 * *$ & .013 & $.100 *$ & $.086^{*}$ \\
\hline Confidence in Problem Solving & .012 & .057 & -.056 & .059 \\
\hline Confidence in Creativity \& Design & .064 & -.081 & .043 & -.004 \\
\hline \multicolumn{5}{|l|}{ Full Model Statistics } \\
\hline$R^{2}$ & .082 & .194 & .065 & .097 \\
\hline Adjusted $R^{2}$ & .077 & .190 & .059 & .092 \\
\hline
\end{tabular}

Note. $* p<.05, * * p<.01, * * * p<.001$

\section{Model 1: Interest in Science}

The full model significantly predicts $8 \%$ of the variance for interest in science, $F(5,909)=16.25, p<.001$ with interest in problem solving $(\beta=.275, p<.001)$ as a positive predictor and interest in creativity and design $(\beta=$ $-.116, p<.001)$ a negative predictor. Results indicate that girls who are interested in problem solving are more likely to be interested in science; however, girls who are interested in creativity and design are less likely to be interested in science.

\section{Model 2: Interest in Math}

The full model significantly predicts $19 \%$ of the variance for interest in math, $F(5,909)=43.89, p<.001$. In block 2 and in the full model, interest in problem solving $(\beta=.407, p<.001)$ was the only statistically significant predictor for interest in math.

\section{Model 3: Interest in Computer}

The full model significantly predicts $6 \%$ of the variance for interest in computer, $F(5,909)=12.54, p<$ .001 . In the first block, age $(\beta=-.083, p<.001)$ was a significant negative predictor suggesting that as girls get older they are less likely to be interested in computers. However, age dropped out of statistical significance in the second 
and third blocks. In the full model, both interest in problem solving $(\beta=.210, p<.001)$ and interest in creativity and design $(\beta=.100, p<.05)$ predicted greater interest in computers.

\section{Model 4: Interest in Engineering}

The full model significantly predicts $9 \%$ of the variance for interest in engineering, $F(5,909)=19.56, p<$ .001 . Once again, both interest in problem solving $(\beta=.237, p<.001)$ and interest in creativity and design $(\beta=.086$, $p<.05)$ positively predicted greater interest in engineering, although interest in creativity and design to a lesser extent than interest in problem solving.

\section{Extracurricular Involvement}

The overarching goal of K-12 STEM outreach programs is to create an awareness of STEM opportunities and foster interest in pursuing, persisting, and graduating with a STEM degree, and finally choosing a STEM career post-graduation. K-12 STEM outreach programs may find it beneficial to know the extracurricular involvement of girls who are more interested in problem solving and creativity and design. Outreach efforts can then be specialized and targeted to specific extracurricular activities. Furthermore, encouraging girls who are not already participating in these programs to participate may foster interest in problem solving and creativity and design potentially leading to an increased interest in STEM subjects.

Figure 1 provides participants' mean interest for problem solving by activity. The top five activities that had the highest participant mean interest in problem solving were 1) State Science Fair, 2) Project Lead the Way, 3) environmental clubs, 4) math clubs, and 5) Future Farmers of America. The activities with the lowest participant mean interest in problem solving included sports/athletics and band/music.

\section{Interest in Problem Solving}

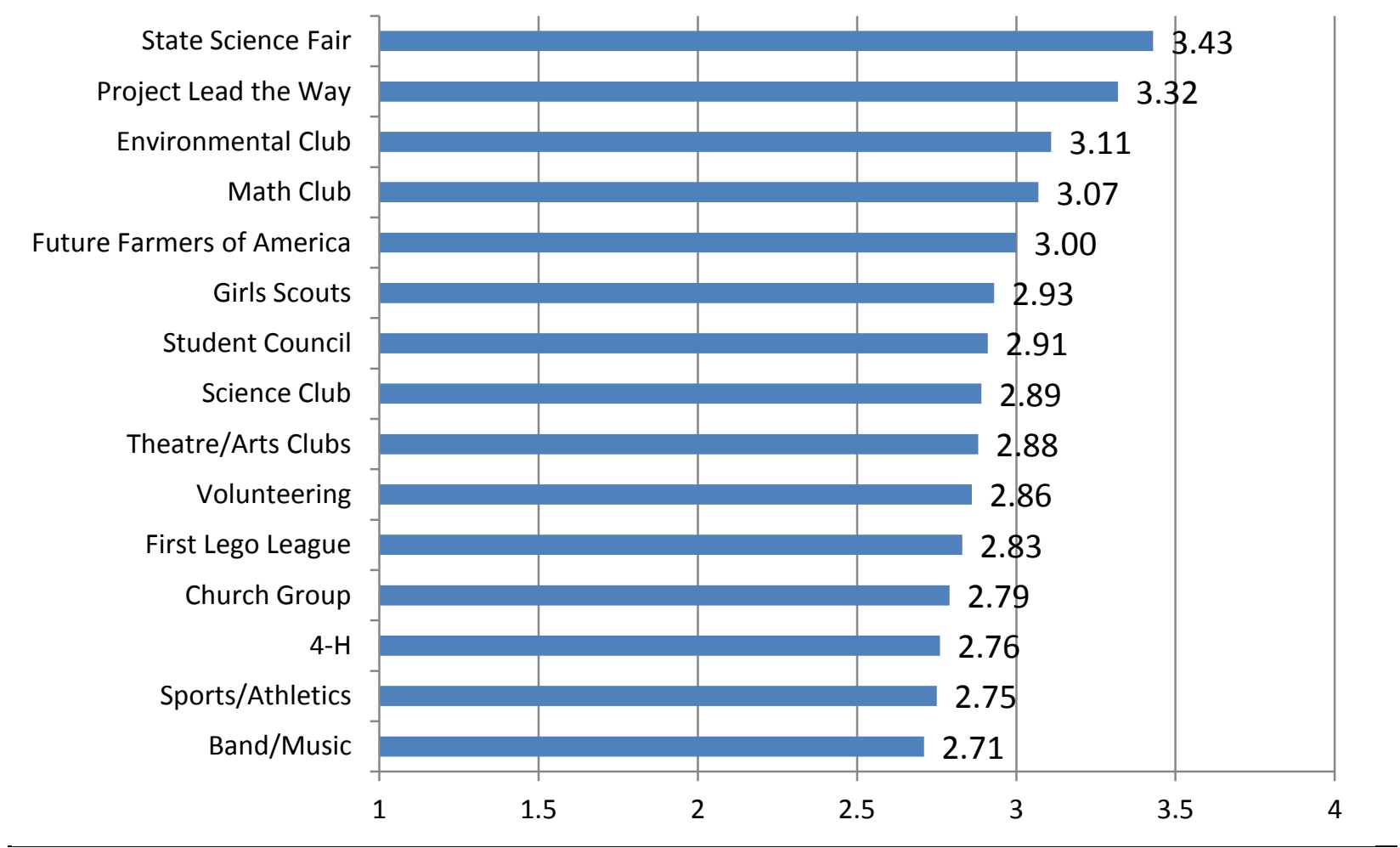

Figure 1. Participants' Mean Interest in Problem Solving by Activity 
Figure 2 illustrates participants' mean interest for creativity and design by activity. The top five activities with the highest participant mean interest in creativity and design were 1) Student Council, 2) State Science Fair, 3) volunteering, 4) environmental clubs, and 5) math club. The activities with the lowest participant mean interest in creativity and design included Future Farmers of America and Project Lead the Way.

\section{Interest in Creativity and Design}

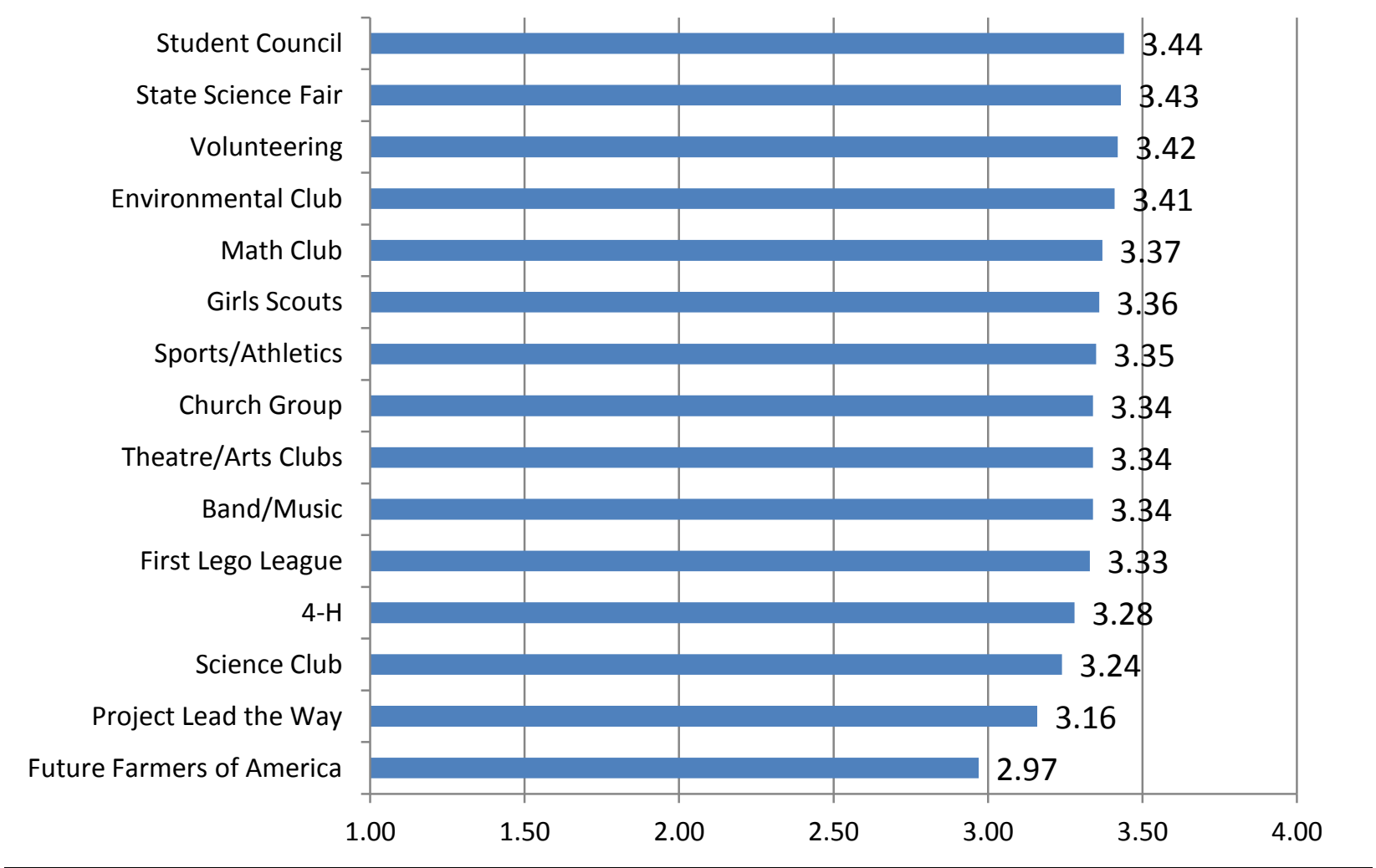

Figure 2. Participants' Mean Interest in Creativity and Design by Activity

\section{DISCUSSION AND CONCLUSION}

According to The National Academy of Engineering (2008), it is important for students to begin associating the possibilities in STEM fields with the need for creativity and real world problem solving skills. The primary focus of this research was to determine the extent to which middle and high school girls' interest and confidence in two fundamental aptitudes for STEM professionals (problem solving, and creativity and design) influence their interest in STEM subjects. Our findings indicate that girls interested in problem solving are likely to be interested in all four STEM subject areas. These results support Modi et al.'s (2012) conclusion that girls who are interested in STEM also indicated an interest in problem solving. Interest in creativity and design was also a significant predictor for interest in computer and engineering subjects. This outcome may be a positive result from programs (e.g., Engineer Your Life, PWSE) implementing the messaging initiatives put forth in Changing the Conversation: Messages for Improving Public Understanding of Engineering (NAE, 2008).

Providing opportunities and developing curriculum that foster girls' interest in problem solving skills is a necessity to further their interest in STEM subjects, college degree programs, and careers. In a recent survey of engineering freshman, students cited the top reasons for what interested them in an engineering degree as "innovation/creativity/design, building things, math/science, practical/real world applications, knowing how things work, and problem solving" (Mertz, 2012, p. 1). Our research supports an approach to cultivating interest in STEM subjects through instructional strategies that involve problem solving experiences (i.e., PBL, PBS, anchored instruction). It is well known that girls have historically chosen careers that have a positive social impact ("helping 
fields"). Using pedagogical strategies like PBL provide students with a collaborative opportunity to solve a complex, realistic or real-world problem that not only motivates students to learn, but results in the formation of a relevant solution. This real-world problem solving approach creates that much needed link between STEM professions and careers that have positive social impact. In addition, STEM careers require the synergy of cross-disciplinary knowledge. Engaging girls using problem solving based strategies fosters the ability to develop and enhance this transferable skill.

\section{Future Research}

A somewhat unanticipated result in the regression analyses was that interest in creativity and design was a statistically significant negative predictor for girls' interest in science, while interest in creativity and design was a positive predictor for interest in computers and engineering subject areas. Additional research should be conducted to further investigate the disconnect between middle school and high school girls' interest in creativity and design and their interest in science.

What was not addressed in this research study is the extent to which different problem solving approaches to learning (i.e., PBL, PBS, anchored instruction) impacted girls' interest in the STEM subject areas. In other words, is there a problem solving pedagogical approach that works best in fostering interest in STEM subject areas.

Additional research should continue to look at age as a variable for interest in the STEM subject areas. Past research has indicated that girls' interest in STEM subject areas declines as girls get older (AAUW, 1998; Brotman \& Moore, 2008; Catsambis, 1995; Fennema, 2000; Hebert \& Stipek, 2005). In this study, bivariate correlations showed statistically significant relationships between age and interest and confidence in creativity and design, but regression results indicated that age was a not a significant predictor for interest (or declining interest) in any of the STEM subject areas.

Finally, additional research should look further into the relationship between interest in problem solving and creativity and design and those after and extracurricular school programs identified with the highest participant mean interests in problem solving and creativity and design. To what extent do girls participate in activities like State Science Fair, Project Lead the Way, environmental club, and math club because they use problem solving skills in their activities or do the girls who participate in these activities develop interest in problem solving because of the activities themselves. And the same questions arise for the relationship between interest in creativity and design and student council, State Science Fair, volunteering, and environmental club. Furthermore, some activities that indicated high participant interest in problem solving indicated the lowest levels of interest in creativity and design (e.g., Project Lead the Way).

\section{AUTHOR INFORMATION}

Robyn Cooper, Ph.D., is an Assistant Professor of Education and Director of the Doctoral Program in the School of Education at Drake University. She teaches graduate courses in research methods, assessment, education psychology, and statistics. Her research interests include pedagogy and practice focused on increasing girls' involvement and persistence in STEM academics, programs, and careers, environmental stressors that impact student persistence and well-being, and epistemic development. E-mail: robyn.cooper@drake.edu (Corresponding author)

Carol Heaverlo, Ph.D., is the K-12 and Community College Outreach Coordinator for the Program for Women in Science and Engineering at Iowa State University where she coordinates a comprehensive outreach program focused on gender and STEM initiatives impacting nearly 12,000 students each year. She has given numerous presentations on gender equity and worked with educators to develop classroom/extra-curricular strategies with a specific focus on engaging all students in science, technology, engineering, and mathematics. Her research interests include policy and pedagogy as it relates to equity in STEM education. E-mail: heaverlo@iastate.edu 


\section{REFERENCES}

1. Afterschool Alliance (2011). STEM Learning in Afterschool: An Analysis of Impact and Outcomes. http://www.pearweb.org/pdfs/STEMinAfterschool_OutcomesAnalysis.pdf

2. American Association of University Women. (1998). Gender gaps: where our schools fail our children. Washington, DC: Author.

3. American Association of University Women. (2000). Tech-savvy: Educating girls in the new computer age. Washington, DC: Author.

4. American Association of University Women. (2004). Under the Microscope: A decade of gender equity projects in the sciences. Washington, DC: Author.

5. American Association of University Women. (2010). Why so few? Women in science, technology, engineering, and mathematics. Washington, DC: Author.

6. Andre, T., Whigham, M., Hendrickson, A., \& Chambers, S. (1999). Competency beliefs, positive affect, and gender stereotypes of elementary students and their parents about science versus other school subjects. Journal of Research in Science Teaching, 36, 719-747.

7. Anderson, L., \& Gilbride, K. (2003). Bringing engineering to K-12 classrooms: Initiatives and results. Proceedings of the 2003 American Society for Engineering Education Annual Conference.

8. Asiabanpour, B, DesChamps-Benke, N., Wilson, T., Loerwald, M., \& Gourgey, H. (2010). "Bridging" engineering \& art: An outreach approach for middle and high school students. American Journal of Engineering Education, 1(1), 1-19.

9. Baine, C. (2009). Engineers Make a Difference: Motivating Students to Pursue an Engineering Education. Springfield, OR. Bonamy Publishing.

10. Bottoms, G., \& Uhn, J., (2001). Research Brief: Project Lead the Way works: A new type of career and technical program. Southern Regional Education Board. Atlanta, GA.

11. Bransford, J.D., Vye, N., Kinzer, C., \& Risko, R. (1990). Teaching, thinking and content knowledge: Toward an integrated approach. In Jones, B. F., and Idol, L. (eds.), Dimensions of Thinking and Cognitive Instruction, pp. 381-413. Hillsdale, NJ: Erlbaum.

12. Brottman, J.S., \& Moore, R.M. (2008). Girls and science: A review of four themes in the science education literature. Journal of Research in Science Teaching, 45(9), 971-1002.

13. Bruyere, B.L., Billingsley, E.D., \& O'Day, L. (2009). A closer examination of barriers to participation in informal science education for Latinos and Caucasians. Journal of Women and Minorities in Science and Engineering, 15, 1-14.

14. Campbell, P., Jolly, E., Hoey, L., \& Perlman, L. (2002). Upping the numbers: Using research-based decision making to increase the diversity in the quantitative disciplines. Newton, MA: Education Development Center, Inc.

15. Catsambis, S. (1995). Gender, race, ethnicity, and science education in the middle grades. Journal of Research in Science Teaching, 32, 243-257.

16. Colley, K. (2008). Project-based science instruction: A primer. The Science Teacher, 75(8), 23-28.

17. Darke, K., Clewell, B., \& Sevo, R. (2002). Meeting the challenge: The impact of the National Science Foundation's Program for Women and Girls. Journal of Women and Minorities in Science and Engineering, 8(3/4), 285-303.

18. Davis, F. J., Lockwood-Cooke, P.L., \& Hunt, E. M. (2011). Hydrostatic pressure project: Linked-class problem-based learning in engineering. American Journal of Engineering Education, 2(10), 43-50.

19. Denissen, J.J., Zarrett, N.R., \& Eccles, J.S. (2007). I like to do it, I'm able, and I know I am: Longitudinal couplings between domain-specific achievement, self-concept, and interest. Child Development, 78(2), 430-447.

20. Diaz, N.V., \& Cox, M.F. (2012). An overview of the literature: Research in P-12 engineering education. Advances in Engineering Education, 3(2), 1-37.

21. Fennema, E. (2000). Gender and mathematics: What is known and what do I wish was known? Paper presented at the Fifth Annual Forum of the National Institute for Science Education. Retrieved from http://www.wcer.wisc.edu/archive/nise/news_Activities/Forums/Fennemapaper.htm

22. Green, S.B., \& Salkind, N.J. (2011). Using SPSS for Windows and Macintosh: Analyzing and understanding data $\left(\sigma^{\text {th }}\right.$ ed.). Upper Saddle River, NJ: Pearson Prentice Hall. 
23. Hebert, J., \& Stipek, D. (2005). The emergence of gender differences in children's perceptions of their academic competence. Applied Developmental Psychology, 26(2), 276-295.

24. Hmelo-Silver, C.E. (2004). Problem-based learning: What and how do students learn? Educational Psychology Review, 16(3), 235-266.

25. Hunt, E.M., Lockwood-Cooke, P.L., \& Kelley, J. (2010). Linked-Class problem-based learning in engineering: Method and evaluation. American Journal of Engineering Education, 1(1), 79-88.

26. Jacobs, J.E., Lanza, S., Osgood, D.W., Eccles, J.S., \& Wigfield, A. (2002). Changes in children's selfcompetence and values: Gender and domain differences across grades one through twelve. Child Development, 73, 509-527.

27. Jeffers, A., Safferman, A., \& Safferman, S. (2004). Understanding K-12 engineering outreach programs. Journal of Professional Issues in Engineering Education and Practice, 130(2), 95-108.

28. Kafai, Y.B., (1998). Video games designs by girls and boys: Variability and consistency of gender differences. In J. Cassell and H. Jenkins, eds., From Barbie to Mortal Kombat: Gender and Computer Games. Cambridge, MA: MIT Press.

29. Katehi, L., Pearson, G., \& Feder, M., Eds, Committee on K-12 Engineering Education. National Academy of Engineering and National Research Council of the National Academies. (2009). Engineering in K-12 Education: Understanding the Status and Improving the Prospects. Washington, D.C.: National Academies Press. http://www.nap.edu/catalog.php?record_id=12635

30. King, P.M., \& Kitchener, K.S. (1994). Developing Reflective Judgment: Understanding Promoting Intellectual Growth and Critical Thinking in Adolescents and Adults. San Francisco: Jossey-Bass.

31. Koch, J. (2002). Gender issues in the classroom. In W.M. Reynolds \& G.E. Miller (Eds.). Educational psychology. Volume 6 of the Handbook of Psychology. New York: John Wiley \& Sons.

32. Krajcik, J.S., Blumenfeld, P., Marx, R.W., Bass, K.M., Fredricks, J., \& Soloway, E. (1998). Middle school students' initial attempts at inquiry in project-based science classrooms. Journal of Learning Sciences, 7 , 313-350.

33. Mertz, B.E. (2012). Analysis of first-year engineering student essays on engineering interests for institutions of different Carnegie classifications. Paper presented at the American Society for Engineering Education conference.

34. Miller, P.H., Blessing, J.S., \& Schwartz, S. (2006). Gender differences in high-school students' views of science. International Journal of Science Education, 28(4), 362-381.

35. Modi, K., Schoenberg, J., \& Salmond, K. (2012). Generation STEM: What girls are saying about science, technology, engineering, and math. New York: Girl Scouts Research Institute.

36. National Academy of Engineering (2006). The Bridge: A call for K-16 Engineering Education. Washington, DC: The National Academies Press.

37. National Academy of Engineering (2008). Changing the conversation: Messaging for improving public understanding of engineering. Washington, DC: The National Academies Press.

38. National Academy of Sciences (NAS) (2010). Rising above the gathering storm, Revisited: Rapidly approaching category 5. Washington, DC: Author.

39. National Science Board (2010). Science and Engineering Indicators 2010. (NSB-10-01). Arlington, VA: National Science Foundation.

40. Partnership for $21^{\text {st }}$ Century Skills. (2008a). Key findings: Are they really ready to work? Retrieved from http://www.p21.org/storage/documents/key findings joint.pdf

41. Partnership for $21^{\text {st }}$ Century Skills. (2008b). Preparing every child for the $21^{\text {st }}$ century. Retrieved from http://www.cpb.org/stations/reports/PreparingChildren21stCentury.pdf

42. Planty, M., Hussar, W., Snyder, T., Kena, G., KewalRamani, A., Kemp, J., Bianco, K., Dinkes, R. (2009). The Condition of Education 2009 (NCES 2009-081). National Center for Education Statistics, Institute of Education Sciences, U.S. Department of Education. Washington, DC.

43. Sadler, P.M., Sonnert, G., Hazari, Z., \& Tai, R. (2012). Stability and volatility of STEM career interest in high school: A gender study. Science Education, 96(3), 411-427.

44. Schraw, G., Dunkle, M.E., \& Bendixen, L.D., (1995). Cognitive processes in well-defined and ill-defined problem solving. Applied Cognitive Psychology, 9, 1-16.

45. Shuen, J., Elia, A., Xu, K., Chen, C., Jiang, A., Litkowski, E., Bonhivert, A., Hsu-Kim, H., \& SchwartzBloom, R., (2011). FEMMES: A One-Day Mentorship Program to Engage $4^{\text {th }}-6^{\text {th }}$ Grade Girls in STEM Activities. Journal of Women and Minorities in Science and Engineering, 17(4), 295-312. 
46. Silva, E. (2008). Measuring skills for the $21^{\text {st }}$ century. Washington, DC: Education Sector.

47. Simpkins, S.D., Davis-Kean, P.E., \& Eccles, J.S. (2006). The intersection between self-concept and values: Links between beliefs and choices in high school. New Directions for Child and Adolescent Development, 110, 31-47.

48. Sullivan, J.F., (2006) "Broadening Engineering's Participation - A Call for K-16 Engineering Education," The Bridge. Washington, DC: National Academies Press, Vol. 36, No. 2. Summer 2006. http://www.nae.edu/NAE/bridgecom.nsf/weblinks/MKEZ-6QDLB3?OpenDocument\#Author Based on a talk given October 10, 2005 at the NAE Annual Meeting.

49. Tabachnick, B.G., \& Fidell, L.S. (2007). Using multivariate statistics $\left(5^{\text {th }}\right.$ ed). Needham Heights, MA. Allyn and Bacon.

50. Wenglinsky, H. (2000). How teaching matters: Bringing the classroom back into the discussions of teacher quality. Princeton, NJ: Educational Testing Service.

51. White, H. (2010). STEAM not STEM -Whitepaper [White Paper]. STEAM not STEM. Retrieved from, http://steam-notstem.com/articles/whitepaper/ 